\title{
OPEN Author Correction: The impact of decellularization methods on extracellular matrix derived hydrogels
}

\author{
Julia Fernández-Pérez (i) \& Mark Ahearne
}

Correction to: Scientific Reports https://doi.org/10.1038/s41598-019-49575-2, published online 17 October 2019

This Article contains errors in Reference 46 which was incorrectly given as:

Odorico, J. S. et al. Extracellular matrix scaffold and hydrogel derived from decellularized and delipidized human pancreas. Sci. Rep. 8, 1-16 (2018)

The correct reference is listed below as Reference 1 :

\section{Reference}

1. Sackett, S. D. et al. Extracellular matrix scaffold and hydrogel derived from decellularized and delipidized human pancreas. Sci. Rep. 8, 10452 (2018).

\begin{abstract}
(c) (i) Open Access This article is licensed under a Creative Commons Attribution 4.0 International License, which permits use, sharing, adaptation, distribution and reproduction in any medium or format, as long as you give appropriate credit to the original author(s) and the source, provide a link to the Creative Commons license, and indicate if changes were made. The images or other third party material in this article are included in the article's Creative Commons license, unless indicated otherwise in a credit line to the material. If material is not included in the article's Creative Commons license and your intended use is not permitted by statutory regulation or exceeds the permitted use, you will need to obtain permission directly from the copyright holder. To view a copy of this license, visit http://creativecommons.org/licenses/by/4.0/.
\end{abstract}

(C) The Author(s) 2019 